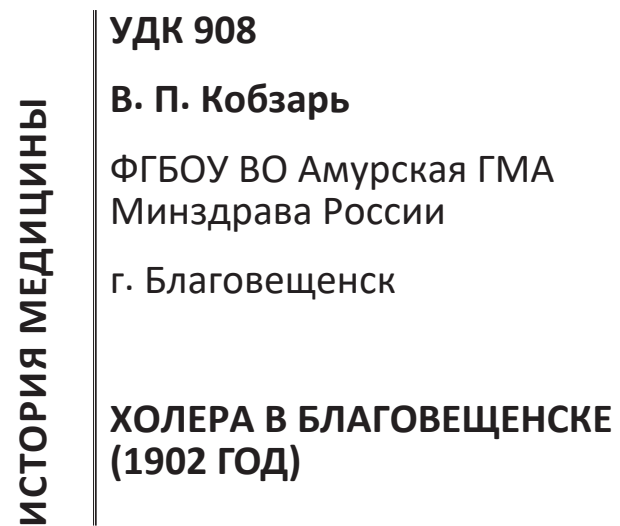

Холера - одна из древнейших болезней человека. Первые упоминания холеры датируются предположительно пятым веком до нашей эры. Первое научное описание эпидемии холеры сделал в 1563 г. португальский врач Гарсия дель Уэрто [1].

В истории холеры условно выделяют четыре периода. Первый от древних времен до 1817 г. (холера эндемическая болезнь стран, расположенных в бассейне рек Ганг и Брахмапутра); второй - с 1817 по 1926 г. (холера распространиласьна Филиппины, в Китай,Японию, Африку, Европу, Россию); третий - с 1926 по 1960 г. (холера вновь наблюдалась в эндемичных регионах Юго-Восточной Азии); четвертый - с 1961 г. (по неполным данным ВО3, с 1961 по 1984 г. в мире холерой переболело 1,5 млн человек) [1].

В течение второго периода в истории холеры человечество пережило шесть опустошительных пандемий:1817-1823, 1826-1837, 1846-1862, 1864-1875, 1883-1896, 1902-1925 годы. В 1902 году с эпидемией холеры боролись на Амуре.

В первых числах июня из Маньчжурии в Благовещенск прибыл пароход «Александр». Оказалось, один из членов экипажа был болен холерой. Он умер. Пароход со всей командой и пассажирами был задержан на обсервацию (карантин) на 30 суток. Но в ближайшие дни появились новые заболевшие холерой, уже в городе.

Городское самоуправление Благовещенска действовало решительно. Первым делом был сформирован отряд дезинфекторов (один фельдшер и четыре санитара). Заведовать отрядом был назначен амурский окружной врач М.И. Чердынцев. Дума пригласила «всех желающих врачей на холерное время с выдачей вознаграждения» по 300 р. в месяц (в «мирное время» это зарплата главного врача городской больницы). Всем, желающим работать санитарами в холерных больницах, предлагалась плата 100 р. в месяц. (в обычных обстоятельствах - зарплата старшего фельдшера городской больницы; рабочие на приисках, «на своих харчах», получали в месяц 45 р.) [2].

На базе переселенческих бараков, примыкавших к городской больнице (в западной части города) спешно было открыто холерное отделение на 50 кроватей. Его организацией занимались благовещенские врачи М.П. Чердынцев и П.И. Бенедиктович.

Под руководством доктора И.Д. Прищепенко, в помещении бывшей мельницы Соколова (в восточной части города), была организована городская холерная больница. «В больнице два отделения - мужское и женское, - пишет корреспондент «Амурской газеты», посетивший лечебницу. - В палатах просторно, светло, кроме кроватей и столиков ничего нет. Полы моют несколько раз в день, причем везде тщательно дезинфицируется. Во дворе, в отдельном помещении, кухня. В другом, отдельном, специально и спешно (в течение четырех дней) построенном бараке - комнаты для врача, фельдшерицы, смотрителя и т.д. и кладовая. Во дворе разбито несколько палаток, в которых помещаются служители. Здесь же, во дворе, большая, сложенная в один день, печь с котлом для дезинфекции белья больных. Белье складывается в бочку, у которой в одном дне проверчено много отверстий. Бочка ставится поверх котла с кипящей водой. Эта паровая баня или, по выражению одного дезинфектора, «пекло», продлевается полтора часа.

Строится вторая печь для дезинфекции. Под навесом запасные кровати. Поперек двора протянуты веревки и на них повешено вымытое больничное белье.Привыходе изпалатыхолерных больных служитель подал таз с раствором сулемы и попросил опустить в раствор подошвы обуви. В больнице поочередно дежурят врачи».

Местные газеты регулярно сообщали о том,

\begin{abstract}
Резюме В статье рассказывается об эпидемии холеры в Благовещенске летом 1902 года, о мерах борьбы, которые принимало местное самоуправление, об участии врачей областного центра в борьбе с эпидемией, о холерном бунте, стихийно возникшем и успешно ликвидированном.
\end{abstract}

Ключевые слова: эпидемия холеры, Амур, Благовещенск.

\section{CHOLERA IN BLAGOVESCHENSKY (1902 YEAR)}

V.P. Kobzar

FSBI HED Amur SMA MH, Blagoveshchensk, Russia

Abstract The article describes the organization of the fight against the cholera epidemic in Blagoveshchensk in the summer of 1902.

Key words: epidemic of cholera, Amur, Blagoveshchensk. 
сколько человек заболело, выздоровело, умерло и остается на излечении в больницах города. Промежуточный «итог» подвело одно из изданий 4 августа: «С 3 по 31 июля в Благовещенске заболело 300, умерло 205, выздоровело 72, в больнице остается 23 человека». [4]

«Ввиду усиления заболевших холерой» и острой нехватки медицинского персонала было решено пригласить из Томского университета десять студентов-медиков.

Было ли реализовано это предложение, неизвестно.

Большой проблемой стал набор служебного персонала. «В холерных больницах до сих пор нет женской прислуги. Несмотря на громадное жалованье благовещенские обывательницы не решаются идти ухаживать за больными женщинами. Первой откликнулась фельдшерица А.И. Разсохина (занимала очень хорошее место кассирши), она знакома с холерой с 1892 года, участвовала в борьбе снею в Самарской губернии» [3].

Кроме крупномасштабных мероприятий по устройству больниц, были приняты и другие меры: 1000 рублей выделено на оборудование новых ассенизационных телег, 300 рублей - на постройку шести ретирад (общественные туалеты) на берегах Зеи и Амура. Во дворе городской управы (сегодня - ул. Ленина, 130) сложили огромную печь с двумя большими котлами для «приготовления прокипяченной воды в большом количестве» для раздачи всем желающим. На берегу Амура (в районе теперешней площади им. Ленина) открыли бесплатную чайную. Каждому посетителю здесь выдавали заварку, кусок сахара и кипяток. Ежедневно в чайной расходилось по 30-40 ведер кипятка.

При первом появлении холеры обыватели вспомнили Баклановскую холерную микстуру, «которая делала чудеса во время холеры 1892 года». Впервые ее применил известный кавказский герой 40-50-х годов генераллейтенант Я.П. Бакланов. Во время холерной эпидемии 1848-1849 годов Бакланов, еще в чине полковника, командовал донским казачьим №20 полком, находившемся на Кавказе в укреплении Куринском. «Лишь только открылась холера по соседству этого укрепления, Бакланов заготовил лекарство, получившее позже название «Баклановская микстура», из следующих народных средств. В штоф объемом в кварту (кварта - мера жидких и сыпучих тел обычно немного больше литра) влить 2 стакана крепкого винного уксуса, столовую ложку острой водки, 1 ложку белой нефти, 1 ложку белого скипидара, положить 2 золотника (русская мера веса = 4,26 грамма) нашатыря, 1 золотник камфоры, 2 ложки мелко источенного круглого перца, долить штоф обыкновенной водкой. При появлении первых признаков заболевания принимать по $1 \frac{4}{4}$ винной рюмки, долитой водкой.
Выпив этот прием, больной должен ходить, пока вспотеет, а потом лечь и, укрывшись, уснуть. Если у больного уже судороги и понос, он должен выпить половину чайной чашки микстуры, долитую водкой. При запущенной болезни, когда больной уже посинел, в рот ему следует влить полную чайную чашку микстуры» [5]. Про приказу Бакланова микстуру принимали все (тем, кто пытался отказываться, грозило наказание плетьми), и никто из двухтысячного гарнизона Куринского укрепления холерой не заболел.

Летом 1902 года в Благовещенске ежедневно заболевало 20-30 человек. 28 июля газеты сообщали: «Часть улицы Вознесенской между Садовой и Благовещенской (сейчас Красноармейская между 50 лет Октября и Шевченко) - все больны. В одном дворе умерли все обитатели». Обстановка была напряженная. Детонатором эксцессов могло стать что угодно, например, праздник.

20 июля в городе были организованы торжества. Как написала «Амурская газета», «население города, всяк по-своему, праздновало годовщину своего избавления от бомбардировки 1900 года. Некоторая часть наших граждан сочла своим священным долгом в этот день напиться, если не до потели сознания, то, по крайней мере, до геройского настроения» [4].

В тот день заболело 30, умерло 13 человек. С самого утра санитары возили через весь город одних - в холерную больницу, других - на кладбище. Наблюдая это, подвыпившие горожане начали распускать слухи о том, что «хватают пьяных, хоронят живых, отравляют здоровых». Особо рьяные стали нападать на санитаров. В одном случае последним пришлось бросить умершего на улице, а самим спасаться в ближайшем полицейском участке.

Во второй половине дня возле холерной больницы собралась толпа пьяных и экзальтированных горожан, грозя ее разнести. О беспорядках доложили амурскому вицегубернатору С.Н. Таскину. Приехав, он уговорил всех разойтись, приказал закрыть питейные заведения в районе больницы, организовал охрану больницы и разъезжающих санитаров.

Но в других районах города обыватели продолжали «отмечать» и обсуждать холерные дела. К вечеру у холерной больницы вновь собралась толпа, в этот раз человек в четыреста. Кричали, что доктора отравляют здоровых, требовали, чтобы не хоронили умерших в просмоленных гробах, требовали снять охрану у домов, в которых кто-то заболел холерой (на постах возле этих домов стояло 26 городовых - почти весь состав городской полиции).

По просьбе вице-губернатора С.Н. Таскина командир 21-го полка выслал патрульных. Они 
прибыли к холерной больнице около 11 часов ночи. При виде военных толпа разошлась. На следующий день, 21-го июля, в Семинарской роще (около холерной больницы) в помощь полиции разместили роту солдат и двадцать конных артиллеристов. В этот же день в городе были закрыты и опечатаны все питейные заведения. Порядок был восстановлен.

Принимаемые энергичные меры дали реальный результат-холера пошла на спад. Во времяхолеры состояли на городской службе, несли ночные и дневные дежурства при врачебном управлении и горбольнице врачи П.И. Бенедиктович, С.П. Образцов, А.Е. Поздеев, Ф.Я. Бочкарев, (?) Паскевич, (?) Беляков, В.В. Вертоградский, В.А. или В.П. Павлов, И.Д. Прищепенко, Я.Л. Таубер, И.М. Хоммер, А.А. Тихонравов, А.М. Файнберг, М.П. Чердынцев и женщина-врач М.Н. Бочкарева. Кроме того, Я.Л. Таубер осматривал пароходы, Паскевич был командирован в Айгун, И.Д. Прищепенко организовал вторую холерную больницу, М.П. Чердынцев заведовал холерным обозом [11].

\section{Литература}

1.Холера. Обзор. ФБУН ГНЦВиБ «Вектор». [Электронный pecypc]. URL: http://vector.nsc.ru (Сайт)

2.Хроника//Амурская газета. 30.06.1902. (Газета).

3.Исторические аспекты формирования санитарно-эпидемиологической службы Приамурья в период освоения
Дальнего Востока//ФБУЗ «Центр гигиены и эпидемиологии в Амурской области». [Электронный ресурс]. URL: http:// www.cge-amur.ru (Сайт)

4.Жуков А. Улица русских инженеров// Молодой Дальневосточник. 2013. №44. (Газета).

5.Коробкова И. Догнать неузнанное время// Тихоокеанская звезда. 2016. 23 марта. (Газета)

6.Мизь Н. Эпидемии в истории Владивостока//

Владмедицина.Ру. [Электронный ресурc]. URL: http:// vladmedicina.ru (Сайт)

7. Хроника.// Екатеринбургская неделя. 1892. №27. (Газета) СОУНБ им. В. Г. Белинского. [Электронный ресурс]. URL: http://elib.uraic.ru (Сайт)

8. Благовещенцы. 1858-1920-е гг. Именной и биографический справочник-указатель. /Амурский областной краеведческий музей им. Г.С. Новикова-Даурского. [Электронный ресурc]. URL: http://museumamur.org (Сайт).

Статья поступила в редакцию 12.12.2017

\section{Координаты для связи}

Кобзарь Валентина Петровна, член Союза журналистов России, ответственный редактор научно-практического издания «Амурский медицинский журнал» ФГБОУ ВПО Амурская ГМА Минздрава России. E-mail: acpress@mail.ru

Почтовый адрес ФГБОУ ВО Амурская ГМА Минздрава России: 675000 Благовещенск, ул. Горького, 95.

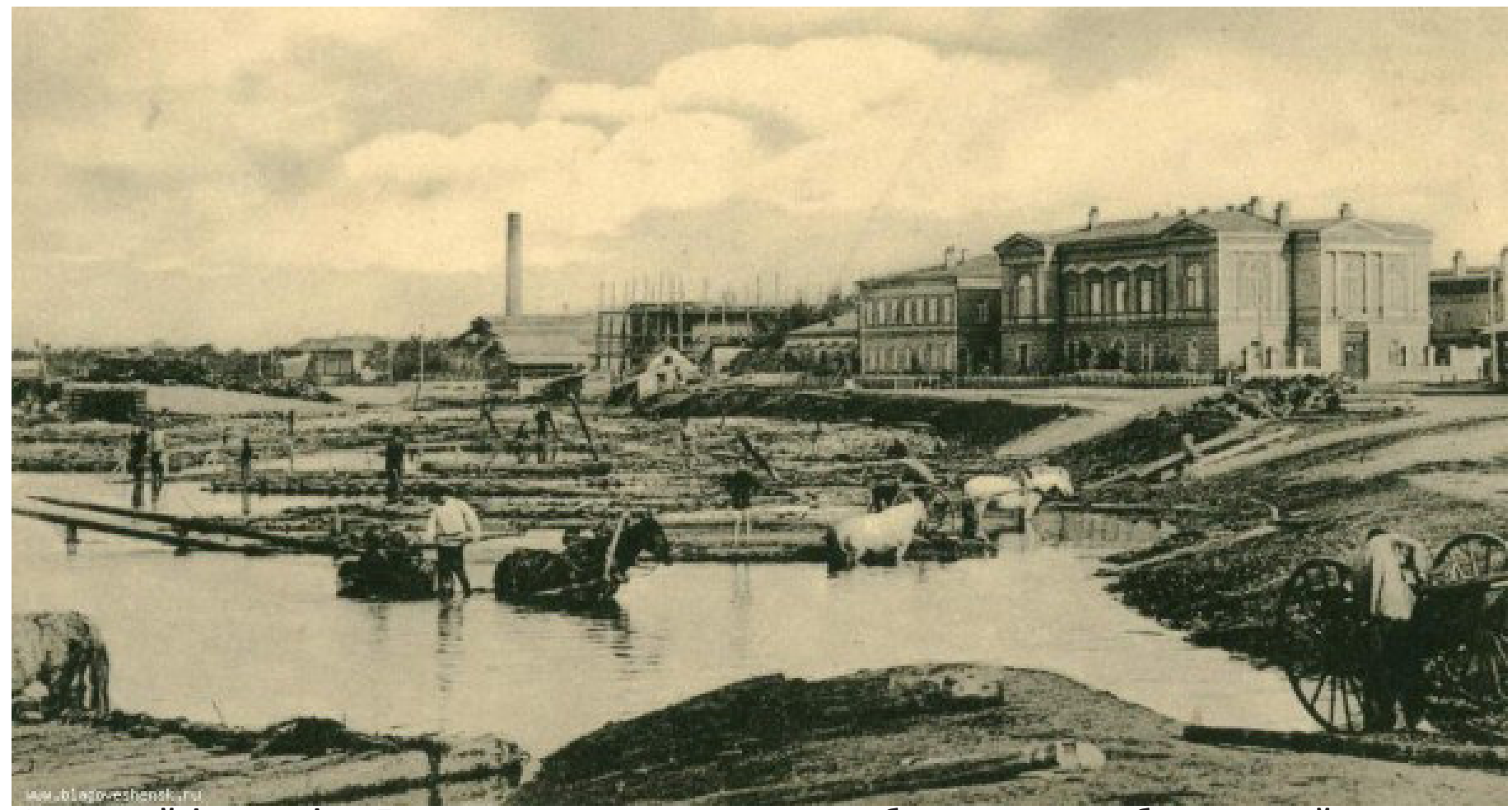

На страрой фотографии Благовещенска справа здание госбанка, вдали труба городской электротсанции. На переднем плане водовоз: много лет благовещенцы воду брали из Амура. 